\title{
Isolation and characterization of multiple drug resistance bacterial pathogens from waste water in hospital and non-hospital environments, Northwest Ethiopia
}

Feleke Moges $^{1 *}$, Mengistu Endris ${ }^{1}$, Yeshambel Belyhun ${ }^{2,3}$ and Walelegn Worku ${ }^{4}$

\begin{abstract}
Background: The importance of bacterial isolates from waste water environment as a reservoir of antibiotic resistance and a potential source of novel resistance genes to clinical pathogens is underestimated. This study is aimed at to isolate and characterize public health important bacteria from waste water in hospital and non- hospital environments and evaluate the distribution of multiple drug resistance bacteria in the study area.

Methods: A cross-sectional study was conducted at Gondar from January-June 2012. The hospital waste water was taken from different sections of the Gondar University Teaching Hospital. Non- hospital environment samples were taken at different sites of the university campuses, Gondar College of Teachers education, and soft drink factory in Gondar. Samples were aseptically collected, transported and processed with in two hours following standard procedure. Identified organisms were assessed for different antibiotics following Kirby-Bauer disk diffusion method. All data was registered and entered in to SPSS version 16 computer program. P-values less than 0.05 were taken as statistically significant.
\end{abstract}

Result: A total of 60 waste water samples were processed for the presence of drug resistance pathogens. Among the total samples 113 bacterial isolates were recovered and of these 65 (57.5\%) were from hospital environment and 48 (42.5\%) were from non-hospital environment. The most frequently identified bacterium was Klebsiella spp. 30 (26.6\%) followed by Pseudomonas spp. 19(16.8\%), E. coli (11.5\%) and Citrobacter spp (11.5\%), and Staphylococcus aureus (8.2\%). The over all prevalence of multiple drug resistance (MDR) in this study was 79/113 (69.9\%). MDR in hospital environment was found to be 53/68 (81.5\%) while in non hospital environment was found to be $26 / 48$ (54.2\%).

Conclusions: Multiple drug resistance to the commonly used antibiotics is high in the study area. The contamination of waste water by antibiotics or other pollutants lead to the rise of resistance due to selection pressure. The presence of antibiotic resistance organisms in this waste water should not be overlooked. Since this organisms may be vital to the safety and well-being of patients who are hospitalized and individual susceptible to infection. Therefore, proper waste water treatment plant should be established and improved sanitary measure should be practice.

Keywords: Hospital environment, Multiple drug resistance, Non-hospital environment, Waste water

\footnotetext{
* Correspondence: Mogesfeleke@gmail.com

1 Department of Medical Microbiology, College of Medicine and Health

Sciences, University of Gondar, Gondar, Ethiopia

Full list of author information is available at the end of the article
} 


\section{Background}

The use of antibiotics and spread of antibiotic resistance in clinical settings is a well recognized problem, but antibiotics and antibiotic resistance as environmental problems and pollutants have largely been overlooked. As a result, the increasing incidence of resistance to a wide range of antibiotic agents by a variety of organisms is a major concern facing modern medicine.

Hospital wastewater can be hazardous to public health and ecological balance since it can contain many kinds of pollutants such as radioactive, chemical and pharmaceutical wastes and also pathogenic microorganisms [1]. Uncontrolled and excessive use of antibiotics by human and animals results an increase in antibiotic resistance and cause the spread of resistance genes in environmental samples such as hospital waste water [2]. Studies have demonstrated that hospital wastewater is highly selective environments and that they contribute to the high rates of resistant bacteria that are being discharged in the natural environment [3]. As demonstrated by Colomer-Lluch et al., the occurrence of bacteriophages from samples of animals fecal wastes can be environmental vectors for the horizontal transfer of antibiotic resistance genes [4].

Therefore, antibiotic resistance is not only found in pathogenic bacteria but also in environmental organisms inhabiting terrestrial and aquatic habitats. Higher numbers of resistant bacteria occur in polluted habitats compared with unpolluted habitats, indicating that humans have contributed substantially to the increased proportion of resistant bacteria occurring in the environment [5].

Antibiotics exert a selection in favor of resistant bacteria by killing or inhibiting growth of susceptible bacteria; resistant bacteria can adapt to environmental conditions and serve as vectors for the spread of antibiotic resistance [6]. The main risk for public health is that resistance genes are transferred from environmental bacteria to human pathogen [6,7]. The volume of antibiotics used in hospitals and private households and released into effluent and municipal sewage indicates a selection pressure on bacteria [8]. Waste effluent from hospitals contains high numbers of resistant bacteria and antibiotic residues at concentrations able to inhibit the growth of susceptible bacteria $[9,10]$. As a result, hospital waste effluent could increase the numbers of resistant bacteria in the recipient sewers by both mechanisms of introduction and selection for resistant bacteria [11].

As reported by Gelaw [12] postoperative surgical site infections in the hospital were mainly due to presence of contamination of medical equipment, environmental surfaces, air and hands of health personnel. The knowledge about the risk perception of healthcare workers (HCWs) toward healthcare waste management in health care facilities of Gondar town confirms that, only $60 \%$ of the HCWs had adequate risk perception that improperly managed healthcare wastes could transmit infection to HCWs and patients [13]. Practice of self medication was also a problem [14] and injection and antibiotic use of the hospital is not to the standard of WHO limit [15]. It is believed that, these factors may serve as a selective pressure and contribute to the increase drug resistance strains in the hospital environment. In Ethiopia especially, in Northwest Ethiopia there is no data concerning resistance profiles of microorganisms isolated from hospital or community sewage. This study is therefore, attempt to generate original local data and examine the magnitude of drug resistance pathogens in hospital and non-hospital environments in Gondar, Ethiopia.

\section{Methods}

\section{Study setting and sampling}

A cross-sectional study was conducted from January-June 2012 at Gondar University Hospital, Gondar College of Teachers Education, Pepsi soft drink factory and other campuses of the faculty of Social, Natural and Computational Sciences, University of Gondar.

Gondar University Hospital is a tertiary level teaching hospital that provides health service to over five million inhabitants in Northwest Ethiopia, and is located 737 Km North from the capital city, Addis Ababa, Ethiopia.

\section{Hospital waste water samples}

Thirty three untreated wastewater samples were collected from Gondar University hospital at different sites. The superficial wastewater samples were collected at the open surface flowing cross the hospital campus and sample were taken at $100 \mathrm{~m}$ upstream of the inlet (site1) and dawn stream that goes out (outlet) the hospital (site 2). The other samples were collected at different outlets within the different section of the hospital and designating as waste water from Intensive Care Unit and Surgery (operation theatre) (site 3); Pathology Laboratory (site 4), Hospital Laboratory and Sterilization room (site 5); Pediatric ward (site 6); Gynecology and Obstetric ward (site 7); Internal Medicine ward (site 8); General ward (site 9); Orthopedic and Surgical ward (site 10).

\section{Non- hospital waste water samples}

Twenty seven waste water samples were collected from four different sources other than sites of the university hospital: Social science faculty (site 11), Natural and computational sciences faculty (site 12), Gondar College of Teacher's Education (site 13) and Pepsi soft drink factory (Site 14).

Sample processing, isolation and identification of bacteria Samples were transported to the laboratory in cool conditions and processed within two hours of collection. A $100 \mathrm{~mL}$ aliquot of waste water of serial ten-fold dilutions 
for each sample was filtered through a $0.22 \mu \mathrm{m}$ pore membrane (Millipore, Billerica, MA) which was then placed on plate count agar and incubated aerobically at $37^{\circ} \mathrm{C}$ for $24-48$ hours. After incubation, based on colony morphology representative colonies were picked and sub-cultured on different selective and differential media such as blood agar, MacConkey agar, and pseudomonas agar. After obtaining pure colonies and recording important features such as haemolysis on blood agar isolated organisms were identified biochemically in a systematic way following standard methods [16].

\section{Antimicrobial susceptibility testing}

Once the bacteria is isolated and identified from each sample collected, the standard Kirby-Bauer disk diffusion method was used to determine the antimicrobial susceptibility profiles of the isolates [17]. Bacterial inoculum was prepared by suspending the freshly grown bacteria in $4-5 \mathrm{ml}$ sterile nutrient broth and the turbidity was adjusted to that of a $0.5 \mathrm{McF}$ arland standard. The antimicrobial susceptibility testing was performed using Mueller-Hinton medium against ampicillin (10 $\mu \mathrm{g})$, chloramphenicol $(30 \mu \mathrm{g})$, ciprofloxacin $(5 \mu \mathrm{g})$, clindamycin $(2 \mu \mathrm{g})$, erythromycin $(15 \mu \mathrm{g})$, gentamicin $(10 \mu \mathrm{g})$, methicillin $(5 \mu \mathrm{g})$, vancomycin, $(30 \mu \mathrm{g})$, streptomycin $(10 \mu \mathrm{g})$, trimethoprim-sulfamethoxazole $(5 \mu \mathrm{g})$, tetracycline $(30 \mu \mathrm{g})$, nalldixic acid $(30 \mu \mathrm{g})$, cephalothin $(30 \mu \mathrm{g})$, cefotaxime $(30 \mu \mathrm{g})$, kanamycin $(30 \mu \mathrm{g})$. The plates were incubated aerobically at $37^{\circ} \mathrm{C}$ for $18-24$ hours. The zones of inhibition were measured and compared with National Committee for Clinical Laboratory Standards (NCCLS) guidelines [18]. Escherichia coli ATCC 25922 and $P$. aeruginosa ATCC 27853 were used for quality control. Data was entered in to SPSS version 16 computer program. P-values less than 0.05 were taken as statistically significant.

\section{Results}

A total of 60 waste water samples were processed for the presence of drug resistance bacterial pathogens. Of these samples $85 \%$ of the samples were positive to one or more isolates. Among the total samples 113 bacterial isolates were recovered and 65 (57.5\%) were from hospital environment and 48 (42.5\%) were from non-hospital environment (Table 1).

Most frequently isolated bacterium was Klebsiella spp. 30 (26.5\%) followed by Pseudomonas spp. 19 (16.8\%), E. coli (11.5\%) and Citrobacter spp (11.5\%), and S. aureus (8.2\%). Two Shigella species were isolated from hospital environment (Table 2).

All the isolates of $S$. aureus were resistant to ampicillin $(100 \%)$. One isolates of $S$. aureus was resistant to 11 antimicrobials including methicillin. However, no isolates of $S$. aureus was recovered to be vancomycin resistant
Table 1 Distribution of samples taken from hospital and non-hospital environments, Gondar 2012

\begin{tabular}{lllll}
\hline Sample sites & $\begin{array}{l}\text { Total } \\
\text { samples }\end{array}$ & $\begin{array}{l}\text { Sample } \\
\text { positive }\end{array}$ & $\begin{array}{l}\text { Samples } \\
\text { negative }\end{array}$ & $\begin{array}{l}\text { Total bacterial } \\
\text { isolates } \\
\text { recovered }\end{array}$ \\
& $\mathbf{N}(\%)$ & $\mathbf{N}(\%)$ & $\mathbf{N ~ ( \% )}$ & $\mathbf{N}(\%)$ \\
\hline $\begin{array}{l}\text { Hospital } \\
\text { environment }\end{array}$ & $33(55)$ & $28(54.9)$ & $5(55.6)$ & $65(57.5)$ \\
$\begin{array}{l}\text { Non- hospital } \\
\text { environment }\end{array}$ & & & & \\
$\quad \begin{array}{l}\text { College of } \\
\text { teacher's education }\end{array}$ & $7(11.7)$ & $7(13.7)$ & 0 & $13(11.5)$ \\
$\quad \begin{array}{l}\text { Maraki campus } \\
\text { Tewodrose campus }\end{array}$ & $9(10)$ & $6(11.8)$ & 0 & $15(13.3)$ \\
$\quad \begin{array}{l}\text { Pepsi soft drink } \\
\text { factory }\end{array}$ & $5(8.3)$ & $5(9.8)$ & $4(44.4)$ & $7(6.2)$ \\
$\quad \begin{array}{l}\text { Sub total } \\
\text { Overall }\end{array}$ & $27(45)$ & $23(45.1)$ & $4(44.4)$ & $48(42.5)$ \\
\hline
\end{tabular}

(Table 3). Multiple drug resistance was also common in gram negative isolates to commonly used antibiotics in the study area. All isolates of E. coli, Citrobacter spp. and Enterobacter spp. were 100\% resistant to ampicillin. The over all resistance of gram-negative bacteria to ampicillin was $97 \%$, followed by cephalotin $49 \%$, cotrimoxazole $38 \%$, tetracycline $37 \%$, naldixic acid $36 \%$, cefotaxime $33 \%$; least resistant being ciprofloxacin 12\% (Table 4).

Among Gram negative bacterial isolates the most striking multiple drug resistant isolate which was resistant to 12 antibiotics tested was Enterobacter spp. followed by Klebsiella spp. to 11 antibiotics, Pseudomonas spp. to 10 antibiotics.

Table 2 Number of bacteria isolated at each sampling points from hospital and non-hospital environments Gondar, 2012

\begin{tabular}{lccc}
\hline Bacterial isolates & $\begin{array}{c}\text { Hospital } \\
\text { env't } \\
\text { No. (\%) }\end{array}$ & $\begin{array}{c}\text { Non hospital } \\
\text { env't } \\
\text { No. (\%) }\end{array}$ & Total \\
\hline E. coli & $8(12.3)$ & $5(10.4)$ & $13(11.5)$ \\
Klebsiella spp* & $19(29.2)$ & $11(22.9)$ & $30(26.6)$ \\
Pseudomonas aeruginosa & $14(21.5)$ & $5(10.4)$ & $19(16.8)$ \\
Enterococci + CoNS** & $5(7.7)$ & $3(6.3)$ & $8(7.1)$ \\
S. aureus & $5(7.7)$ & $5(10.4)$ & $10(8.8)$ \\
Shigella Spp & $2(3.1)$ & - & $2(1.8)$ \\
Citrobacter spp & $5(7.7)$ & $8(16.7)$ & $13(11.5)$ \\
Enterobacter spp & $2(3.1)$ & $5(10.4)$ & $7(6.2)$ \\
Others*** & $5(7.7)$ & $6(12.5)$ & $11(9.7)$ \\
Total & $\mathbf{6 5 ( 1 0 0 )}$ & $\mathbf{4 8 ( 1 0 0 )}$ & $\mathbf{1 1 3 ( 1 0 0 )}$ \\
\hline
\end{tabular}

${ }^{*}$ Klebsiella spp. (K. Pneumoniae $=23 ; K$. oxytoca $=2 ; K$. ozaenae $=5$ ). ${ }^{*}$ CoNS = Coagulase Negative Staphylococci.

***Others (Providencia spp $=4$; Morganella $\mathrm{spp}=3$; Proteus spp $=2$; Serratia sp. $=1$; Edwardsiella sp. $=1$ ). 
Table 3 Resistance rate of gram positive isolates to commonly used antibiotics in Gondar, 2012

\begin{tabular}{|c|c|c|c|c|c|c|c|c|c|c|c|c|c|c|c|}
\hline \multirow[t]{2}{*}{ Bacterial isolates } & \multicolumn{15}{|c|}{ Antibiotic resistance $\mathrm{N}(\%)$} \\
\hline & Met & Van & DA & GN & SXT & ERY & TTC & CAF & CIP & NA & S & AMP & CRO & KF & СТX \\
\hline Enterococci + CoNS $(n=8)$ & $2(25)$ & - & $2(25)$ & - & $2(25)$ & $3(38)$ & $2(25)$ & $2(25)$ & $1(13)$ & $4(50)$ & $1(13)$ & $5(63)$ & - & - & - \\
\hline S. aureus $(n=10)$ & $1(10)$ & - & $2(20)$ & $1(10)$ & - & $2(20)$ & $1(10)$ & $2(20)$ & $1(10)$ & $6(60)$ & $1(10)$ & $10(100)$ & $1(10)$ & $1(10)$ & $2(20)$ \\
\hline Total $(n=18)$ & $3(17)$ & - & $4(22)$ & $1(6)$ & $2(11)$ & $5(28)$ & $3(17)$ & $4(22)$ & $2(11)$ & $10(56)$ & $2(11)$ & $15(83)$ & $1(6)$ & $1(6)$ & $2(11$ \\
\hline
\end{tabular}

MET = Methicillin; VAN = Vancomycin; DA = Clindamycin; GN = Gentamycin; SXT = Cotrimoxazole; ERY = Erytromycin; TTC = Tetracycline; CAF = Chloramphinicol; $\mathrm{CIP}=$ Ciprofloxacin, NA = Naldixic acid; $\mathrm{S}=$ Streptomycin; $\mathrm{AMP}=$ Ampicillin $\mathrm{CRO}=$ Ceftriaxone; $\mathrm{KF}=$ Cephalothin; $\mathrm{CTX}=\mathrm{Cefotaxime}$.

Among 113 isolates $1(0.9 \%)$ was susceptible to all antibiotics tested, 33(29.2\%) were resistant only for one antibiotics, 22 (19.5\%) were for 2 antibiotics, 9 (7.9\%) were for 3 antibiotics, $14(12.4 \%)$ were for 4 antibiotics, 34 (30.1\%) resistant to 5 or more antibiotics (Table 5). The over all prevalence of multiple drug resistance (MDR) (two or more drugs) in this study was 79/113 (69.9\%). Multiple drug resistance in hospital environment was found to be $53 / 65$ (81.5\%) while in non-hospital environment was found to be $26 / 48$ (54.2\%). When we consider isolates showing resistant to more than 5 antibiotics, the distribution of MDR isolates in hospital environment still found to be higher than non-hospital environments with the rate of $30 / 65$ (46.2\%) and $4 / 48$ $(8.3 \%)$, respectively.

\section{Discussion}

Among the total isolates of bacteria, 65 (57.5\%) were from hospital environment and 48 (42.5\%) were from non-hospital environments. The rate of isolation of bacterial pathogens in the hospital environment was higher than the non-hospital environment, this was statistically significant $(\mathrm{P}=0.01)$. Similar trends was reported by Guardabassi et al., that factors other than the indiscriminate use of antibiotics in human medicine, animal husbandry, and agriculture may disrupt the microbial balance in favor of resistant bacteria. In particular, wastewater from pharmaceutical plants could play a role in the selection of antibiotic-resistant bacteria in sewage [19].

In the present study frequently identified bacterium was Klebsiella spp. 30 (26.6\%) followed by Pseudomonas spp. 19 (16.8\%), E. coli (11.5\%) and Citrobacter spp (11.5\%), and S. aureus (8.2\%). Similar reports by Ekhaise and Omavwoya in Benin hospital showed that the bacterial genera, Klebsiella, Pseudomonas and Serratia were the most frequently distributed isolates in the hospital wastewater [20]. Similar study in Rio de Janeiro, Brazil reported that the most common multi-resistant extended spectrum beta-lactamase (ESBL) producing isolates from hospital waste water were Klebsiella pneumoniae, Enterobacter cloacae and E. coli [21].

Multiple drug resistance was also common in gram positive isolates to commonly used antibiotics in the study area. All isolates of $S$. aureus were resistant to Ampicillin (100\%). One isolates of S. aureus was found to be resistant to 11 antimicrobials including methicillin. As indicated by Abulreesh, multidrug resistant staphylococci (S. aureus and coagulase negative Staphylococci) have been a common problem and recovered from diverse environmental sources, such as drinking water supplies, foodstuffs, the mucosa of humans and farm animals and hospital environments which can be important public health concern [22]. The number of MRSA isolates in this study was lower than reports from municipal waste water in U. S. A [23]. This variation may be

Table 4 Resistance rate of gram negative isolates to commonly used antibiotics in Gondar, 2012

\begin{tabular}{|c|c|c|c|c|c|c|c|c|c|c|c|c|}
\hline \multirow[t]{2}{*}{ Bacterial isolates } & \multicolumn{12}{|c|}{ Antibiotic resistance $\mathrm{N}(\%)$} \\
\hline & GN & SXT & TTC & CAF & CIP & NA & $\mathrm{S}$ & AMP & CRO & KF & CTX & $\mathrm{K}$ \\
\hline E. coli $(n=13)$ & $1(8)$ & $5(38)$ & $5(38)$ & $1(8)$ & $3(23)$ & $4(31)$ & $1(8)$ & $13(100)$ & $2(15)$ & $3(23)$ & $3(23)$ & $2(15)$ \\
\hline Klebsiella spp $(\mathrm{n}=30)$ & $6(20)$ & $10(33)$ & $8(27)$ & $4(13)$ & $5(17)$ & $7(23)$ & $9(30)$ & $30(100)$ & $8(27)$ & $12(40)$ & $10(33)$ & $6(20)$ \\
\hline Pseudomonas aeruginosa $(n=19)$ & $1(5)$ & $11(58)$ & $10(53)$ & $7(37)$ & $1(5)$ & $10(53)$ & $3(16)$ & $18(95)$ & $3(16)$ & $16(84)$ & $11(58)$ & $6(32)$ \\
\hline Shigella spp. $(\mathrm{n}=2)$ & - & - & - & - & - & $1(50)$ & - & $1(50)$ & $1(50)$ & $2(100)$ & $2(100)$ & - \\
\hline Citrobacter spp $(n=13)$ & $2(15)$ & $4(31)$ & $5(38)$ & $3(23)$ & - & $5(38)$ & $5(38)$ & $13(100)$ & $1(8)$ & $4(31)$ & $1(8)$ & $2(15)$ \\
\hline Enterobacter spp $(n=7)$ & $1(14)$ & $3(43)$ & $4(57)$ & $1(14)$ & $1(14)$ & $2(29)$ & $2(29)$ & $7(100)$ & $1(14)$ & $3(43)$ & $1(14)$ & $1(14)$ \\
\hline Other G-ve $(n=11)$ & $2(18)$ & $3(27)$ & $3(27)$ & $1(9)$ & $1(9)$ & $5(46)$ & $3(27)$ & $10(91)$ & $3(27)$ & $7(64)$ & $3(27)$ & $3(27)$ \\
\hline Total $(n=95)$ & $13(14)$ & $36(38)$ & $35(37)$ & $17(18)$ & $11(12)$ & $34(36)$ & $23(24)$ & $92(97)$ & $19(20)$ & $47(49)$ & $31(33)$ & $20(21)$ \\
\hline
\end{tabular}

GN = Gentamycin; SXT = Cotrimoxazole; $T \mathrm{C}=$ Tetracycline; $\mathrm{CAF}=$ Chloramphinicol; $\mathrm{CIP}=$ Ciprofloxacin, NA = Naldixic acid; $\mathrm{S}=$ Streptomycin; $\mathrm{AMP}=\mathrm{Ampicillin}$; $\mathrm{CRO}=$ Ceftriaxone; $\mathrm{KF}=$ Cephalothin; $\mathrm{CTX}=$ Cefotaxime; $\mathrm{K}=$ Kanamycin. 
Table 5 Over all rate of multiple drug resistance (resistant to 2 or more antibiotics) in isolates from hospital and non-hospital waste water, 2012

\begin{tabular}{|c|c|c|c|c|c|c|c|}
\hline \multirow[t]{2}{*}{ Study sites } & \multicolumn{6}{|c|}{ Antibiotic resistance $\mathrm{N}(\%)$} & \multirow[b]{2}{*}{ Total } \\
\hline & Ro & $\mathbf{R} 1$ & $\mathrm{R} 2 *$ & R3 & R4 & $\geq \mathbf{R} 5^{* *}$ & \\
\hline Hospital environment & 0 & $12(18.5)$ & $9(13.8)$ & $4(6.1)$ & $10(15.4)$ & $30(46.2)$ & $65(100)$ \\
\hline Non-Hospital environment & $1(2.1)$ & $21(43.8)$ & $13(27.8)$ & $5(10.4)$ & $4(8.3)$ & $4(8.3)$ & $48(100)$ \\
\hline Total & $1(0.9)$ & $33(29.2)$ & $22(19.5 \%)$ & $9(7.9)$ & $14(12.4)$ & $34(30.1)$ & $113(100)$ \\
\hline
\end{tabular}

R0 = Susceptible to all antibiotics tested; R1 = Resistance to 1 antibiotic; R2 = Resistance to 2 antibiotics; R3 = Resistance to 3 antibiotics; R4 = Resistance to 4 antibiotics; $\mathrm{R} 5$ and above $=$ Resistance to 5 or more antibiotics. ${ }^{*} \mathrm{P}=$ value $(>2$ antibiotics $)=(\mathrm{COR} 3.741 .49-9.53,95 \% \mathrm{Cl}, \mathrm{P}=0.001)$.

${ }^{* *} \mathrm{P}=$ value $(\geq \mathrm{R} 5$ antibiotics $)=(\mathrm{COR} 9.43,2.80-35.03 ; 95 \% \mathrm{Cl}, \mathrm{P}=0.00001)$.

due to early introduction of methicillin in USA than the place of the present study, Ethiopia.

Multiple drug resistance was also common in gram negative isolates to commonly used antibiotics in the study area. E. coli, Klebsiella spp. Citrobacter spp. and Enterobacter spp. were $100 \%$ resistant to Ampicillin. This finding is inconsistent from reports in Brazil that the overall, resistance rates were low in the isolates of E. coli, P. aeruginosa, K. pneumoniae and A. baumannii and the susceptibility pattern of E.coli and Klebsiella for ampicillin was found 40\% and 70\%, respectively [24]. Among all isolates of Gram negative bacteria $97 \%$ of the isolates were resistant to ampicillin, followed by cephalotin $49 \%$, cotrimoxazole $38 \%$, tetracycline $37 \%$, naldixic acid $36 \%$ cefotaxime $33 \%$.

The resistant pattern of gram-negative isolates for ciprofloxacin was lower in the present study, $12 \%$. This was different from other study done in Bangladesh 100\% resistant [25]. The recent circulation of ciprofloxacin in the study area could have contributed to this low prevalence of drug resistance strains. This idea is supported by Moges et al. that, all urinary tract pathogens such as E. coli, Klebsiella spp. Citrobacter spp were $100 \%$ susceptible to ciprofloxacin before 10 years in the same study area, where ciprofloxacin start circulating in the market [26]. Multiple drug resistance from 2-12 antibiotics was found to be 79/113 (69.9\%). Multi-drug resistance in hospital environment was 53/65 (81.5\%) while in non hospital environment was $26 / 48$ (54.2\%). Isolates from hospital environment were found 3.74 times resistant for many drugs than isolates from non-hospital environment (COR 3.74 1.49-9.53, $95 \% \mathrm{CI}, \mathrm{P}=0.001)$. When we consider isolates showing resistant to more than 5 antibiotics, still hospital environment 30/65 (46.2\%) show higher resistant pattern than non-hospital environment $4 / 48(8.3 \%)$. This was statistically significant (COR 9.43, 2.80-35.03; 95\% CI, P = 0.00001). Similar finding demonstrate that, waste effluent from hospitals contains high numbers of resistant bacteria and antibiotic residues at concentrations able to inhibit the growth of susceptible bacteria $[9,10]$.

\section{Conclusions}

Multiple drug resistance to the commonly used antibiotics is high in the study area. This was even higher in hospital waste water. The contamination of water by antibiotics or other pollutants lead to the rise of resistance due to selection pressure. The presence of antibiotic resistant organisms in this waste water should not be overlooked. Since this organisms may be vital to the safety and well-being of patients who are hospitalized as well as individuals who are susceptible to infection. Therefore, proper waste water treatment plant should be established and improved sanitary measure should be practice.

\section{Competing interests}

The authors declare that we have no conflict of interest.

\section{Authors' contributions}

FM designed and prepared the proposal, conduct the field and laboratory work, analyzed data, wrote and revised the manuscript. ME conduct the field and laboratory work, analyzed data, wrote and revised the manuscript. YB Designed the proposal, analyzed data, reviewed the manuscript and edited the language. WW reviewed the manuscript, analyzed data and edited the language. All authors read and approved the final manuscript.

\section{Acknowledgment}

This project was supported by the University of Gondar; General Director, Research and Community Service Core Process, Ref. No: 05/99/04. We are also thankful to Mr. Getnet Ayalew and Amare Kifle for their tireless field work and laboratory assistance in this study.

\section{Author details}

${ }^{1}$ Department of Medical Microbiology, College of Medicine and Health Sciences, University of Gondar, Gondar, Ethiopia. ${ }^{2}$ Department of Immunology and Molecular Biology, College of Medicine and Health Sciences, University of Gondar, Gondar, Ethiopia. ${ }^{3}$ Institute of Virology, Faculty of Medicine, University of Leipzig, Leipzig, Germany. ${ }^{4}$ Department of Environmental and Occupational Health and Safety, College of Medicine and Health Sciences, University of Gondar, Gondar, Ethiopia.

Received: 29 September 2013 Accepted: 2 April 2014 Published: 5 April 2014

\section{References}

1. Sharpe M: High on pollution: drugs as environmental contaminants. J Environ Monit 2003, 5:43-46.

2. Iversen A, Kühn I, Franklin A, Möllby R: High prevalence of vancomycinresistant Enterococci in Swedish wastewater. Appl Environ Microbiol 2002, 68:2838-2842.

3. Yang CM, Lin MF, Liao PC, Yeh HW, Chang BV, Tang TK, Cheng C, Sung CH, Liou ML: Comparison of antimicrobial resistance patterns between clinical and wastewater strains in a regional hospital in Taiwan. Lett Appl Microbiol 2009, 48:560-565.

4. Colomer-Lluch M, Imamovic L, Jofre J, Muniesa M: Bacteriophages carrying antibiotic resistance genes in fecal waste from cattle, pigs, and poultry. Antimicrob Agents Chemother 2011, 55:4908-4911.

5. Pathak SP, Gaur A, Bhattacherjee JW: Distribution and antibiotic resistance among aerobic heterotrophic bacteria from rivers in relation to pollution. J Environ Sci Health A 1993, 28:73-87. 
6. Kruse $\mathrm{H}$ : Indirect transfer of antibiotic resistance genes to man. Acta Vet Scand 1999, 92:59-65.

7. Wegener H, Aarestrup F, Gerner-Smidt P, Bager F: Transfer of resistant bacteria from animals to man. Acta Vet Scand 1999, 92:51-58.

8. Kümmerer $\mathrm{K}$, Henninger A: Promoting resistance by the emission of antibiotics from hospitals and household into effluent. Clinical Microb Infection 2003, 12:1203.

9. Grabow W, Prozesky O: Drug resistance of coliform bacteria in hospital and city sewage. Antimicrob Agents Chemother 1973, 3:175-180.

10. Linton $\mathrm{KB}$, Richmond MH, Bevan R, Gillespie WA: Antibiotic resistance and $\mathrm{R}$ factors in coliform bacilli isolated from hospital and domestic sewage. J Med Microbiol 1974, 7:91-103.

11. Al-Ahmad A, Daschner FD, Kümmerer K: Biodegradability of cefotiam, ciprofloxacin, meropenem, penicillin $\mathrm{G}$, and sulfamethoxazole and inhibition of wastewater bacteria. Arch Environ Contam Toxicol 1999, 37:158-163.

12. Gelaw A: Isolation of Bacterial Pathogens from Patients With Postoperative Surgical Site Infections and Possible Sources of Infections at University of Gondar Hospital, Northwest Ethiopia. (MSc. Thesis). Ethiopia: Addis Ababa University; May 2011.

13. Yenesew MA, Moges HG, Woldeyohannes SM: A cross sectional study on factors associated with risk perception of healthcare workers toward healthcare waste management in health care facilities of Gondar Town, Northwest Ethiopia. Int J Infect Control 2012, 8:i3. doi:10.3396/ijic.8i3.024.12

14. Abay SM, Amelo W: Assessment of self-medication practices among medical, pharmacy, and health science students in Gondar University Ethiopia. J Young Pharm 2010, 2(3):306-310.

15. Admassie E, Begashaw B, Hailu W: Assessment of drug Use practices and completeness of prescriptions in Gondar University teaching referral hospital. IJPSR 2013, 4(1):265-275.

16. Vandepitte A, El-Nageh MM, Stelling JM, Tikhomirov E, Estrela A: WHO Regional Publications, Eastern Mediterranean Series, Volume 15. Alexandria, Egypt: Guidelines for Antimicrobial Resistance Surveillance; 1996.

17. Bauer AW, Kirby WM, Sherirs JC, Turck M: Antibiotic susceptibility testing by standardized single disk method. Amer J Clin Pathol 1966, 45:433-496

18. National Committee for Clinical Laboratory Standards: Performance Standards for Antimicrobial Susceptibility Testing, 7th ed". Approved Standard M2-A7. Wayne, PA: National Committee for Clinical Laboratory Standards; 2000.

19. Guardabassi L, Petersen A, Olsen J, Dalsgaard A: Antibiotic resistance in Acinetobacter spp. isolated from sewers receiving waste effluent from a hospital and a pharmaceutical plant. Appl Environ Microbiol 1998, 61:3499-3502.

20. Ekhaise FO, Omavwoya BP: Influence of hospital wastewater discharged from university of Benin teaching hospital (UBTH), Benin City on its receiving environment. American-Eurasian J Agric Environ Sci 2008, 4(4):484-488.

21. Chagas TP, Seki LM, Cury JC, Oliveira JA, Dávila AM, Silva DM, Asensi MD: Multiresistance, beta-lactamase-encoding genes and bacterial diversity in hospital wastewater in Rio de Janeiro Brazil. J Appl Mlcrobiol 2011, 111(3):572-581.

22. Abulreesh $\mathrm{HH}$ : Multidrug-Resistant Staphylococci in the Environment. InternationalConference on Biotechnology and Environment Management. IPCBEE, vol.18. Singapoore: IACSIT Press; 2011

23. Goldstein RR, Micallef SA, Gibbs SG, Davis JA, He X, George A, Kleinfelter LM Schreiber NA, Mukherjee S, Sapkota A, Joseph SW, Sapkota AR: MethicillinResistant Staphylococcus aureus (MRSA) detected at four U.S. Wastewater treatment plants. Environ Health Perspect 2012, 120:1551-1558.

24. Resende ACB, Soares R, de Bastos A, dos Santos DB, Montalvão ER, do Carmo Filho JR: Detection of antimicrobial-resistant Gram-negative bacteria in hospital effluents and in the sewage treatment station of Goiânia Brazil. O Mundo da Saúde 2009, 33(4):385-391.

25. Islam MJ, Uddin MS, Hakim MA, Das KK, Hasan MN: Role of untreated liquid hospital waste to the development of antibiotic resistant bacteria. J Innov Dev Strategy 2008, 2(2):17-21.

26. Moges F, Mengistu G, Genetu A: Multiple drug resistance in urinary pathogens at Gondar College of Medical Sciences hospital, Ethiopia. E Afr Med J 2002, 79(8):415-419.

doi:10.1186/1756-0500-7-215

Cite this article as: Moges et al:: Isolation and characterization of multiple drug resistance bacterial pathogens from waste water in hospital and non-hospital environments, Northwest Ethiopia. BMC Research Notes 2014 7:215.

\section{Submit your next manuscript to BioMed Central and take full advantage of:}

- Convenient online submission

- Thorough peer review

- No space constraints or color figure charges

- Immediate publication on acceptance

- Inclusion in PubMed, CAS, Scopus and Google Scholar

- Research which is freely available for redistribution 